\title{
ANALISIS KEJADIAN PLASENTA AKRETA DI RSUP H.ADAM MALIK MEDAN TAHUN 2016-2019
}

\author{
Savira Dwi Putri, Iman Helmi Effendi, Hemma Yulfi, Edy Ardiansyah \\ Medical Education, Universitas Sumatera Utara \\ Email: Iman.obgyn@gmail.com
}

\begin{abstract}
Abstrak
Plasenta akreta dianggap sebagai kondisi yang mengancam jiwa dan merupakan penyebab kematiann ibu. Plasenta akreta menyebabkan 7\%-10\% dari kasus kematian ibu didunia. Sectio ceasarea sebelumnya dan operasi rahim merupakan faktor risiko yang paling umum untuk plasenta akreta. Plasenta akreta terjadi ketika vili plasenta menginvasi langsung ke miometrium. Kejadian plasenta akreta meningkat seiring meningkatnya kejadian sectio ceasarea. Desktriptif dengan pendekatan retrospektif. Tahun 2016-Juli 2019 dijumpai 59 kasus plasenta akreta dengan peningkatan jumlah kasus setiap tahunnya. Faktor risiko riwayat sectio ceasarea $(94,8 \%)$. Jenis tindakan sectio ceasarea+histerektomi $(59,3 \%)$. Tidak dijumpai kematian maternal dari tahun 2016 - 2019 Juli. Angka kejadian plasenta akreta meningkat setiap tahunnya dengan faktor risiko dominan plasenta akreta riwayat sectio ceasarea
\end{abstract}

Kata Kunci: Plasenta Akreta, Sectio Ceasarea

\begin{abstract}
Placenta accreta is considered a life-threatening condition and is a cause of maternal death. Placenta accreta causes 7\% -10\% of cases of maternal mortality worldwide. Previous Sectio Ceasarea (SC) and uterine surgery are the most common risk factors for placenta accreta. Placenta accreta occurs when villous placenta invades directly into the myometrium. The incidence of placenta accreta increases with increasing incidence of SC. this wa is descriptive with a retrospective study. From 2016 - July 2019 there were 59 cases of placenta accrete with an increase in the number each year. Risk factor for the history of sectio ceasarea $(94,8 \%)$. Sectio ceasarea + hysterectomy is a procedure of placenta accreta. There were no maternal mortality from 2016 - 2019 up to July. The annual incidence of placenta accreta increases each years mean risk factors dominant placenta accreta is historysectio ceasarea
\end{abstract}

Keyword: Placcenta Accreta, Sectio Ceasarea

\section{Pendahuluan}

Plasenta akreta merupakan implantasi abnormal plasenta pada dinding uterus atau

Copyright holder: Savira Dwi Putri, Iman Helmi Effendi, Hemma Yulfi, Edy Ardiansyah (2022)

DOI : : https://doi.org/10.54543/fusion.v2i02.173

Published by : Rifa Institute 
yang sering disebut dengan istilah plasenta adherent (Fitri \& Mutiara, 2017). Dibagi menjadi tiga berdasarkan histopatologi: plasenta akreta terjadi ketika vili plasenta menginvasi langsung ke myometrium, Plasenta inkreta ketika vili plasenta yang menginvasi ke dalam miometrium, plasenta perkreta ketika plasenta menginvasi lebih dalam dari miometrium hingga ke serosa uterus (Sentilhes et al., 2013).

Plasenta akreta menyebabkan 7\%-10\% dari kasus kematian ibu didunia. Sectio ceasarea (SC) sebelumnya dan operasi rahim merupakan faktor risiko yang paling umum untuk plasenta akreta maupun perkreta (Sivasankar, 2012). Plasenta akreta dianggap sebagai komplikasi kehamilan yang terkait dengan intrapartum dan berpotensi mengancam jiwa dan perdarahan postpartum (Garmi \& Salim, 2012).

Kejadian plasenta akreta meningkat seiring meningkatnya kejadian SC. Terdapat beberapa faktor risiko plasenta akreta, seperti riwayat sectio caesarea (SC), plasenta previa, in vitro fertilization (IVF), usia ibu > 35 tahun, riwayat kuretase, riwayat miomektomi atau riwayat operasi uterus lainnya selain SC, dan merokok merupakan faktor risiko plasenta akreta (Qatrunnada et al., 2018). Namun faktor risiko yang paling penting untuk terjadinya plasenta akreta adalah riwayat SC sebelumnya (Goh \& Zalud, 2016).

Patogenesis plasenta akreta belum jelas, namun ada beberapa teori yang mengatakan vaskularisasi abnormal akibat proses jaringan parut setelah operasi dengan hipoksia lokal sekunder yang mengarah pada rusaknya desidualisasi dan dapat menyebabakan invasi trofoblas berlebihan ke myometrium ini merupakam teori patogenesis yang paling didukung sampai saat ini (Nunes et al., 2014).

Kebanyakan pasien dengan plasenta akreta tidak menunjukan gejala. Gejala yang berhubungan dengan plasenta akreta adalah termasuk perdarahan pervaginal (Berkley \& Abuhamad, 2013).

\section{Metode Penelitian}

Jenis penelitian ini adalah deskriptif dengan pendekatan retrospektif (Sugiyono, 2015). Populasi dalam penelitian ini adalah seluruh kasus plasenta akreta yang tecatat dalam rekam medik dari Januari 2016-Juli 2019 di RSUP H. Adam Malik Medan. Data yang diperoleh dianalisis dengan menggunakan bantuan aplikasi SPSS (Statistical Packagefor the Social Sciences).

\section{Hasil Penelitian}

Jumlah plasenta akreta dari tahun 2016 - Juli 2019 sebanyak 59 kasus, setiap tahunnya terjadipeningkatan kasus plasenta akreta di RSUP H. Adam Malik Medan.

Tabel 3.1 Kasus plasenta akreta pertahun

$\begin{array}{lll}\text { Tahun } & \begin{array}{l}\text { Frekuensi } \\ (\text { n) }\end{array} & \text { Persentase (\%) }\end{array}$


Savira Dwi Putri, Iman Helmi Effendi, Hemma Yulfi, Edy Ardiansyah

\begin{tabular}{lrr}
\hline 2016 & 1 & 1,7 \\
2017 & 9 & 15,3 \\
2018 & 26 & 44,1 \\
2019 Juli & 23 & 39,0 \\
Total & 59 & 100.0
\end{tabular}

Tabel 3.2 Karakteristik demografi plasenta akreta

\begin{tabular}{lcc}
\hline Karakteristik Demografi & $\begin{array}{c}\text { Frekuensi(n } \\
\text { Usia (Tahun) }\end{array}$ & $\begin{array}{c}\text { Persentase } \\
(\boldsymbol{\%})\end{array}$ \\
$\quad<20$ & 0 & 0 \\
$20-34$ & 40 & 67,8 \\
35 & 19 & 32,2 \\
Gravida & & \\
$1-2$ & 13 & 22,0 \\
$3-5$ & 46 & 78,0 \\
$>5$ & 0 & 0 \\
Pendidika & & \\
nDasar & 8 & 13,6 \\
Menengah & 37 & 62,7 \\
Tinggi & 14 & 23,7 \\
Pekerjaan & & \\
IRT & 34 & 57,6 \\
PNS & 10 & 16,9 \\
Swasta & 3 & 5,1 \\
Wiraswast & 12 & 20,3 \\
a $\quad$ & 100,0 \\
$\quad$ Total (N) & 59 & \\
\hline
\end{tabular}


Tabel 3.3 Karakteristik klinis plasenta akreta

\begin{tabular}{lcc}
\hline \multicolumn{1}{c}{$\begin{array}{c}\text { Karakteristik } \\
\text { Klinis }\end{array}$} & Frekuensi(n) & Persentase (\%) \\
\hline Hb (gr/dl) & 8 & 13,6 \\
$<8$ & 35 & 59,3 \\
$8-11$ & 16 & 27,1 \\
$>11$ & & \\
Lama rawat & 33 & 55,9 \\
$<5$ & 26 & 44,1 \\
$>5$ & & \\
Tipe operasi & 32 & 57,2 \\
Elektif & 27 & 45,8 \\
Emergens & & 100, \\
i $\quad$ Total $(\mathbf{N})$ & 59 & 0 \\
\hline
\end{tabular}

Tabel 3.4 Faktor risiko plasenta akreta

\begin{tabular}{lcc}
\hline \multicolumn{1}{c}{ Faktor risiko } & Frekuensi (n) & $\begin{array}{c}\text { Persentase } \\
(\boldsymbol{\%})\end{array}$ \\
\hline Riwayat Sectio Ceasarea & & \\
0 & 3 & 5,1 \\
1 & 19 & 32,2 \\
$\geq 2$ & 37 & 62,7 \\
Riwayat kuretase & & \\
Ada & 23 & 39,0 \\
Tida & 36 & 61,0 \\
k & & \\
Riwayat miomektomi & 4 & 6,7 \\
Ad & 55 & 93,2 \\
a & & \\
NA $\quad$ & 100,0 \\
$\quad$ Total (N) & 59 & \\
\hline
\end{tabular}

Tabel 3.5 Jenis tindakan plasenta akreta 


\begin{tabular}{ccc}
\hline Jenis tindakan & Frekuensi (n) & Persentase (\%) \\
\hline Sectio Ceasarea & 24 & 40,7 \\
Sectio Ceasarea + Histerektomi & 35 & 59,3 \\
Total (N) & 59 & 100.0 \\
\hline
\end{tabular}

\section{Pembahasan}

Berdasarkan penelitian yang dilakukan didapatkan 59 kasus plassenta akreta dari Januari 2016 hingga 2019 Juli. Selama 4 tahun terjadi peningkatan setiap tahunnya yang dikarenakan adanya peningkatan kejadian sectio ceasarea setiap tahunnya, yang dimana salah satu faktor risiko dominan plasenta akreta adalah adanya riwayat sectio ceasarea.

Berdasarkan karakteristik demografi usia bahwa kelompok usia yang terbanyak berisiko mengalami plasenta akreta yaitu usia 20-34 tahun sebanyak 40 kasus $(67,8 \%)$. Usia merupakan faktor risiko yang dapat mempengaruhi kondisi uterus ibu. Pada usia <20 tahun mempunyai risiko lebih tinggi untuk mengalami plasenta aketa dikarenakan endometrium yang belum matang dan pada usia >35 tahun, juga berisiko mengalami plasenta akreta dikarenakan kondisi endometrium sudah mulai mengalami perubahan seperti skerosis pembuluh darah. Hal ini akan menyebabkan penurunan vaskularisasi dan mengakibatkan hipoksia jaringan (Qatrunnada et al., 2018).

Berdasarkan gravida, gravida yang lebih tinggi berisiko terjadinya plasenta akreta. Jumlah gravida yang tinggi berisiko terjadinya plasenta akreta dikarenakan vaskularisasi desidua yang jelek akibat persalinan yang berulang-ulang sehingga menyebabkan endometrium rusak dan aliran darah ke plasenta tidak cukup sehingga vili korialis akan berimplantasi langsung pada miometrium untuk mencari suplai pembuluh darah yang memadai sehingga jumlah gravida yang tinggi dapat menyebabkan plasenta akreta (Sulyastini \& Armini, 2020).

Berdasarkan pendidikan, semakin tinggi tingkat pendidikan seseorang maka akan semakin tinggi pula tingkat pengetahuannya. Demikian pula semakin tinggi pendidikan akan merangsang seseorang untuk selalu mempelajari hal-hal baru termasuk juga hal-hal yang menyangkut kesehatan dirinya (Notoatmodjo, 2003). Pendidikan yang semakin tinggi menyebabkan kemampuan ibu dalam mengatur jarak kehamilan, jumlah anak, dan pemanfaatan fasilitas kesehatan dalam pemeriksaan kehamilan (antenatal care) dan proses persalinan (Ima Rahmawati \& Supanji Raharja, 2018).

Anemia pada ibu hamil akan mengakibatkan pertumbuhan janin yang lambat, kekurangan gizi pada janin, kelahiran prematur, terjadinya gawat janin dan berat badan bayi yang rendah (BBLR). Perdarahan antepartum disebabkan oleh kelainan plasenta, termasuk didalamnya plasenta previa, solusio plasenta dan vasa previa. Kekurangan $\mathrm{Hb}$ dalam darah mengakibatkan kurangnya oksigen yang 
dibawa atau ditransfer ke sel tubuh maupun organ yang vital termasuk uterus. Perdarahan antepartum meningkat kejadiannya pada keadaan yang endometriumnya kurang baik, misalnya pada atrofi endometrium atau kurang baiknya vaskularisasi desidua. Perdarahan postpartum bisa disebabkan karena plasenta belum lahir hingga atau melebihi 30 menit setelah bayi lahir. Hal itu disebabkan plasenta belum lepas dari dinding uterus atau plasenta sudah lepas tetapi belum dilahirkan (Astuti \& Ertiana, 2018).

Luka pada SC terjadi pada dinding abdomen (kulit atau otot perut) dan dinding uterus. Adanya luka post SC merupakan salah satu faktor yang memperpanjang penyembuhan dari luka post SC antara lain adalah suplai darah, infeksi dan iritasi. Dengan adanya mobilisasi dini diharapkan akan menyebabkan perbaikan suplai darah sehingga berpengaruh terhadap kecepatan proses penyembuhan luka post SC. Penyembuhan luka secara normal memerlukan nutrisi yang tepat, ibu post SC haruslebih banyak mengkonsumsi makanan kaya protein, karbohidrat, lemak, vitamin A dan C serta mineral yang sangat berperan dalam pembentukan jaringan baru pada proses penyemuhan luka (Yadianto, 2013).

Wanita dengan plasenta akreta lebih baik melakukan operasi dalam kondisi elektif dan terkontrol dari pada keadaan darurat tanpa persiapan. Untuk meminimalisasi terjadinya komplikasi perdarahan maka dilakukan dengan kondisi elektif dan biasanya dijadwalkan SC pada 37 atau 38 minggu kehamilan.

Melahirkan dengan SC adalah melahirkan janin dengan sayatan pada dinding uterus, sayatan inilah yang dapat mengakibatkan jaringan parut akan terbentuk, SC yang berulang memungkinkan terjadinya komplikasi, salah satu komplikasi yang potensial adalah plasenta abnormal. Riwayat $\mathrm{SC} \geq 2$ kali berisiko lebih besar terkena plasenta akreta yang diakibatkan jaringan parut akan terbentuk pada bekas SC dan akan mengakibatkan hipoksia jaringan, sehingga trofoblas akan menginvasi lebih dalam untuk mendapatkan suplai pembuluh darah yang memadai. Faktor kuatnya perlekatan plasenta disebabkan oleh adanya luka parut akibat persalinan yang berulang-ulang (Dewi et al., n.d.). Riwayat SC juga berperan menaikkan tiga kali risiko plasenta akreta yang menyebabkan perdarahan pasca melahirkan, koagulopati konsumtif dan menyebabkan kematian ibu.

Jenis tindakan pada plasenta akreta yaitu dilakukan dengan ceasarea dan jika terjadi perdarahan yang pasif pervagina maka akan dilakukan tindakan histerektomi untuk pengangkatan rahim yang merupakan salah satu tindakan penganggulangan plasenta akreta.

\section{Kesimpulan}

Hasil penelitian ini dapat disimpulkan bahwa meningkatnya kasus plasenta akreta setiap tahunnya di RSUP H. Adam Malik Medan periode Januari 2016 - 2019 Juli sebanyak 59 kasus. Riwayat sectio ceasarea merupakan faktor risiko yang dominan mempengaruhi plasenta akreta 


\section{BIBLIOGRAFI}

Astuti, R. Y., \& Ertiana, D. (2018). Anemia dalam Kehamilan. Pustaka Abadi. Google Scholar

Berkley, E. M., \& Abuhamad, A. Z. (2013). Prenatal diagnosis of placenta accreta: is sonography all we need? Journal of Ultrasound in Medicine, 32(8), 1345-1350. Google Scholar

Dewi, N. K. D. C., Surya, I. G. N. H. W., \& Mahendra, I. N. B. (n.d.). Karakteristik Ibu Bersalin Dengan Plasenta Previa Di Rumah Sakit Umum Pusat Sanglah Tahun 2018-2019. Google Scholar

Fitri, D. R., \& Mutiara, H. (2017). G2P1A0 Berusia 41 Tahun dengan Plasenta Akreta. Medical Journal of Lampung University, 7(2), 37-41. Google Scholar

Garmi, G., \& Salim, R. (2012). Epidemiology, etiology, diagnosis, and management of placenta accreta. Obstetrics and Gynecology International, 2012. Google Scholar

Goh, W. A., \& Zalud, I. (2016). Placenta accreta: diagnosis, management and the molecular biology of the morbidly adherent placenta. The Journal of MaternalFetal \& Neonatal Medicine, 29(11), 1795-1800. Google Scholar

Ima Rahmawati, R., \& Supanji Raharja, S. O. G. (2018). Hubungan Tingkat Pendidikan dan Riwayat Antenatal Care (ANC) dengan Tindakan Sectio Caesarea. Universitas Muhammadiyah Surakarta. Google Scholar

Notoatmodjo, S. (2003). Pendidikan dan Perilaku Kesehatan, Rineka Cipta. Jakarta, Halaman, 114-131. Google Scholar

Nunes, C., Carvalho, R. M., Araújo, C., Santo, S., Melo, A., \& Graça, L. M. (2014). Diagnosis of placenta accreta by ultrasonography: a "gold standard"? Diagnóstico de placenta accreta por ecografia:"gold standard"? Acta Obstet Ginecol Port, 8(2), 136-140. Google Scholar

Qatrunnada, A., Antonius, P. A., \& Yusrawati, Y. (2018). Faktor Risiko dan Luaran Maternal Plasenta Akreta di RSUP Dr. M. Djamil Padang. Indonesian Journal of Obstetrics \& Gynecology Science, 1(2), 97-102. Google Scholar

Sentilhes, L., Goffinet, F., \& Kayem, G. (2013). Management of placenta accreta. Acta Obstetricia et Gynecologica Scandinavica, 92(10), 1125-1134. Google Scholar

Sivasankar, C. (2012). Perioperative management of undiagnosed placenta percreta: case report and management strategies. International Journal of Women's Health, 4, 451. Google Scholar

Sugiyono, S. (2015). Metode penelitian kombinasi. Bandung: Alfabeta. Google Scholar

Sulyastini, N. K., \& Armini, L. N. (2020). Bahasa Indonesia Implementasi Kehamilan Beresiko di Desa Patas: implementasi kehamilan beresiko di Desa Patas. MIDWINERSLION: Jurnal Kesehatan STIKes Buleleng, 5(2), 390-395. Google Scholar

Yadianto, A. (2013). Hubungan Pengetahuan Gizi Dan Mobilisasi Dini Dengan Penyembuhan Luka Operasi Pada Ibu Post Sectio Caesar Di Rsud Dr. Goeteng Taroenadibrata Purbalinga. Universitas Muhammadiyah Purwokerto. Google 
Scholar

First publication right:

Jurnal Syntax Fusion: Jurnal Nasional Indonesia

This article is licensed under:

(c) (1) (2) 